\title{
A simplified silver phosphate extraction method for oxygen isotope analysis of
}

\section{bioapatite}

Brandi M. Shabaga $^{1 *}$, Hilary Gough $^{2}$, Mostafa Fayek $^{1,2}$, Robert D. Hoppa ${ }^{2}$

${ }^{1}$ Department of Geological Sciences, University of Manitoba, 125 Dysart Road, 240 Wallace Building, Winnipeg, R3T 2N2, Canada

${ }^{2}$ Department of Anthropology, University of Manitoba, 432 Fletcher Argue Building, 15 Chancellor Circle, Winnipeg, R3T 2N2, Canada

*corresponding author Brandi.Shabaga@ umanitoba.ca; (204) 795-5628; fax (204) 474-7623

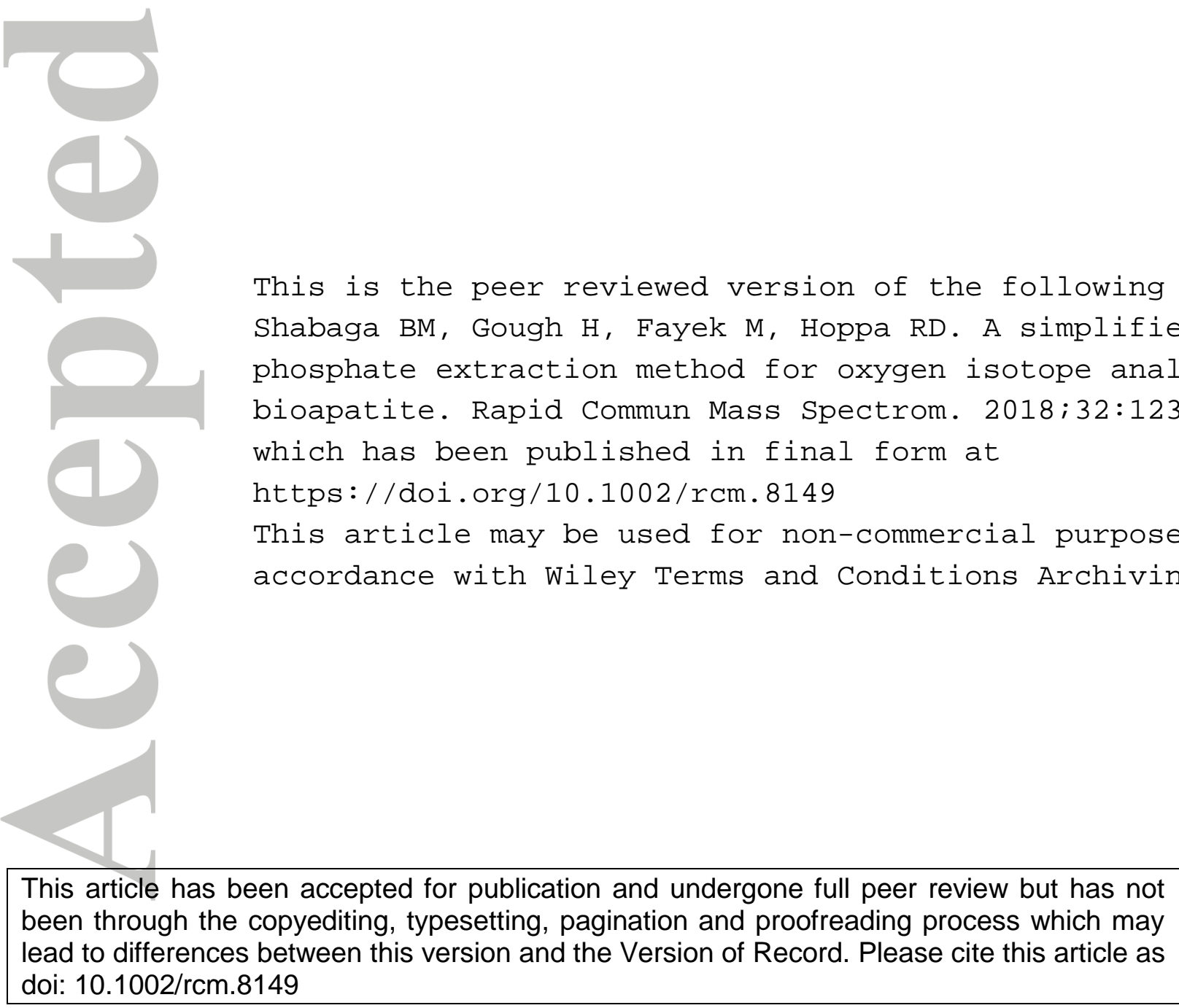

This article is protected by copyright. All rights reserved. 


\section{ABSTRACT}

Rationale: Although phosphatic materials are chemically complex and are prone to exchange oxygen isotopes with their environments, the phosphate $\left(\mathrm{PO}_{4}{ }^{3-}\right)$ component of these materials is robust and retains its original oxygen isotopic composition. As a result, there are currently several methods for the isolation of phosphate oxygen through the precipitation of silver phosphate $\left(\mathrm{Ag}_{3} \mathrm{PO}_{4}\right)$. However, some of these techniques produce $\mathrm{Ag}_{3} \mathrm{PO}_{4}$ of questionable purity, while nearly all are lengthy and/or require relatively large sample sizes.

Methods: Five milligrams of bioapatite from modern cow teeth (enamel and cementum) were pre-treated for removal of organic material prior to digestion in $2 \mathrm{M} H \mathrm{HF}$. The digested samples were titrated with silver ammine solution at $50^{\circ} \mathrm{C}$ to precipitate $\mathrm{Ag}_{3} \mathrm{PO}_{4}$. Oxygen isotopic data were collected using a Thermal Combustion Elemental Analyzer (TC/EA) paired with a Delta $\mathrm{V}^{\text {Plus }}$ isotope ratio mass spectrometer via a ConFlo III universal interface.

Results: The quality of $\mathrm{Ag}_{3} \mathrm{PO}_{4}$ is dependent on effective removal of organic material and the volume of silver ammine solution used during titration. A two-step pre-treatment of $2.5 \%$ $\mathrm{NaOCl}$, followed by a $0.125 \mathrm{M} \mathrm{NaOH}$ solution is the most effective treatment for the removal of organic material from both enamel and cementum. Optimal yields of $\mathrm{Ag}_{3} \mathrm{PO}_{4}$ were achieved using $1.8 \mathrm{~mL}$ of silver ammine solution. The reproducibility of the phosphate $\delta^{18} \mathrm{O}$ compositions ranges from 0.3 to $0.4 \%$ o $(1 \sigma)$ for modern cow teeth.

Conclusions: We present a simplified method for phosphate extraction from organic-rich phosphatic material. Our method gave reproducible $\delta^{18} \mathrm{O}$ values for enamel and cementum from cows' teeth.

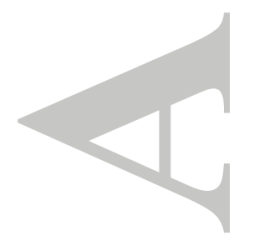




\section{INTRODUCTION}

The measurement of natural variations in light stable isotope ratios has long been recognized as an important tool, and it was initially pioneered for the reconstruction of paleoenvironments. ${ }^{1-9}$ The ${ }^{18} \mathrm{O} /{ }^{16} \mathrm{O}$ isotopic ratio of meteoric water varies geographically as a result of a number of factors related to the hydrologic cycle, including geographic distance from water sources, temperature, and elevation. ${ }^{10}$ Hard tissues composed of bioapatite, such as bone and teeth, reflect this variability and serve as a geographic indicator as oxygen from meteoric water, consumed by the organism, is incorporated into these bio-mineralized tissues as they develop. ${ }^{7}$

Some forms of bioapatite are similar to Ca-phosphate apatites $\left[\mathrm{Ca}_{5}\left(\mathrm{PO}_{4}\right)_{3}(\mathrm{~F}, \mathrm{Cl}\right.$, $\mathrm{OH})$, which is unique to mammalian tissues and is composed of $38 \%$ phosphorus, and $18 \%$ calcium with traces of sodium and magnesium. ${ }^{11-12}$ Mammalian hard tissues have a range of hydroxyapatite-like compositions, with varying degrees of substitutions and crystal sizes. ${ }^{13}$ Dental enamel contains the lowest organic content and is composed of densely packed, wellformed hydroxyapatite crystals, making it significantly more resistant to diagenesis and chemical alteration than the less densely packed hydroxyapatite in bone. ${ }^{11}$ For this reason, enamel is often chosen for chemical and isotopic studies. Dentin and cementum have similar compositions, with less well developed crystallinity and higher organic content. ${ }^{12,14}$ Dental tissues are unique in their utility for migratory and paleoreconstructive studies because enamel and dentin do not undergo tissue turnover in the way that skeletal tissues do, and thus their chemistry is preserved from early stages of life when the tissues formed. Cementum also does not turn over, but continues to form throughout life as a reaction to dental trauma and natural stress, acting to secure the dental root in the surrounding alveolar bone, thus reflecting a more generalized lifetime chemistry. ${ }^{12}$ Because of these characteristics, dental tissues offer the possibility of comparing $\delta^{18} \mathrm{O}$ values from different stages of an organism's life. ${ }^{15-18}$ 
Bio- and Ca-phosphate apatites can accommodate a carbonate component $\left(\mathrm{CO}_{3}{ }^{2-}\right) .{ }^{19-20}$ The oxygen isotopic analysis of the carbonate component is relatively simple and routine. ${ }^{21-25}$ However, the oxygen isotopic composition of carbonate is more prone to isotopic exchange with the environment during post mortem diagenetic alteration than that of phosphate $\left(\mathrm{PO}_{4}{ }^{3-}\right)$, because the $\mathrm{P}-\mathrm{O}$ bond is stronger than the $\mathrm{C}-\mathrm{O}$ bond. ${ }^{26}$ The oxygen isotopic composition of $\mathrm{PO}_{4}{ }^{3-}$ was first reported in the 1960s following the development of methods to isolate phosphate as bismuth phosphate $\left(\mathrm{BiPO}_{4}\right){ }^{8,27}$ The most significant advancement in phosphate extraction techniques has been the transition from isolating $\mathrm{PO}_{4}{ }^{3-}$ as $\mathrm{BiPO}_{4}$, to simplifying the extraction process and precipitating the radical as silver phosphate $\left(\mathrm{Ag}_{3} \mathrm{PO}_{4}\right){ }^{27-31}$ Unlike $\mathrm{BiPO}_{4}, \mathrm{Ag}_{3} \mathrm{PO}_{4}$ is a stable, non-hygroscopic material, which is less susceptible to chemical degradation, making it the preferred analyte for oxygen isotopic analysis of phosphatebearing minerals.

The importance and versatility of using $\mathrm{Ag}_{3} \mathrm{PO}_{4}$ for oxygen isotope studies have led to the development of numerous methods for $\mathrm{Ag}_{3} \mathrm{PO}_{4}$ extraction. ${ }^{29-43}$ These techniques vary drastically in the required sample size (e.g., $1 \mathrm{mg}$ to $\geq 30 \mathrm{mg}$ ), organic material removal treatments, chemical isolation of $\mathrm{Ag}_{3} \mathrm{PO}_{4}$, and analytical protocols (e.g., lasting at least three days and using up to ten different solutions and reagents). ${ }^{29-43}$ Therefore, the objective of this study is to develop a simplified extraction method for precipitating pure, organic-free $\mathrm{Ag}_{3} \mathrm{PO}_{4}$ from small sample sizes of bioapatite $(\sim 5 \mathrm{mg})$.

\section{EXPERIMENTAL}

Modern cow teeth were sectioned to make the internal structures and layers of the teeth visible, allowing for accurate sampling of the enamel and cementum. The exterior and cut surfaces of each tooth were then cleaned by abrasion with fine grit sand paper. Loose powders were removed with ethanol and a delicate task wiper, and a clean diamond-gritted 
rotary tool bit was used to sample each tissue. Care was taken during sampling to avoid any visible abnormalities or signs of chemical alteration. The equipment was thoroughly cleaned with ethanol between use on different tissues and samples. Each sampled tissue was ground and homogenized using an agate mortar and pestle, and stored in glass vials until further processing.

In this study, enamel and cementum samples were pre-treated using a combination of sodium hypochlorite $(\mathrm{NaOCl})$ and sodium hydroxide $(\mathrm{NaOH})^{32,35-36}$ to remove organic matter. This two-step process began by weighing $5 \mathrm{mg}$ of sample into a centrifuge tube and adding $2 \mathrm{~mL} 2.5 \% \mathrm{NaOCl}$ for oxidative removal of organic material. After $24 \mathrm{hrs}$ the samples were centrifuged and the $\mathrm{NaOCl}$ and dissolved organic material were discarded. The samples were then rinsed and centrifuged with distilled water four times before immersing them in 2 $\mathrm{mL}$ of a $0.125 \mathrm{M} \mathrm{NaOH}$ solution for another 24 hours to remove humic substances and any remaining organic matter. The sample pre-treatment concluded with another 4 cycles of centrifugation and rinsing with distilled water.

Once the samples were free of organic material, they were dissolved in $200 \mu \mathrm{L}$ of $2 \mathrm{M}$ hydrofluoric acid (HF) for $24 \mathrm{hrs}$. The sample solutions were then centrifuged and the supernatant was transferred into $50-\mathrm{mL}$ Teflon beakers, leaving behind any precipitated residue (e.g., $\mathrm{CaF}_{2}$ ) in the discarded centrifuge tubes. On a hot plate set at $50^{\circ} \mathrm{C}$, the $\mathrm{HF}$ and dissolved bioapatite was titrated with $1.8 \mathrm{~mL}$ of silver ammine solution $\left(0.2 \mathrm{M} \mathrm{AgNO}_{3} ; 0.3 \mathrm{M}\right.$ $\mathrm{NH}_{4} \mathrm{NO}_{3} ; 0.74 \mathrm{M} \mathrm{NH} \mathrm{OH}^{30}$ ). Crystals of $\mathrm{Ag}_{3} \mathrm{PO}_{4}$ were collected on $0.22 \mu \mathrm{m}$ nitrocellulose filter paper (Millipore; Etobicoke, ON, Canada) using a vacuum filtration set up and rinsed with distilled water. The filter papers were placed in an oven held at $70^{\circ} \mathrm{C}$ until dry. All the chemicals used were reagent grade, and distilled water was used in the preparation of all the solutions. A flowchart of the organic material removal pre-treatment and precipitation method is outlined in Figure 1. 


\section{ANALYTICAL METHODS}

To determine the purity of the $\mathrm{Ag}_{3} \mathrm{PO}_{4}$ produced, and evaluate the effectiveness of the pre-treatment to remove organic material, scanning electron microscopy (SEM) and X-ray diffraction (XRD) were used to characterize the experimental products. Oxygen isotopic ratios were then measured using the pure $\mathrm{Ag}_{3} \mathrm{PO}_{4}$ free of organic contamination.

\subsection{Scanning electron microscopy (SEM) analysis}

Grains of precipitated $\mathrm{Ag}_{3} \mathrm{PO}_{4}$ were mounted on aluminum stubs with carbon tape and carbon coated to prevent sample charging during analysis. A Cambridge Stereoscan 120 scanning electron microscope was used to visually examine grain size and morphology, and a Kevex 7000 Energy Dispersive X-ray spectrometer was employed for initial basic chemical characterization.

\subsection{X-ray diffraction (XRD) analysis}

Oriented smear mounts of $\mathrm{Ag}_{3} \mathrm{PO}_{4}$ were made by finely crushing and grinding the precipitate in an agate mortar and pestle, centering the powdered sample on a glass slide, and adding several drops of ethanol to spread the wet slurry across the slide with a needle tool. A Siemens D5000 (Bruker Canada Ltd, Milton, ON, Canada) powder diffractometer, scanning $6^{\circ}-66^{\circ}$ (diffraction angle $2 \theta$ ), with $\mathrm{Cu} \mathrm{K} \alpha$ radiation, at a step size of $0.02^{\circ}$ and a scan time of 1 second, was used to analyze the material. The spectra were interpreted offline using MDI Jade mineral identification software.

\subsection{Oxygen isotope analysis}


Silver phosphate was analyzed using a Thermal Combustion Elemental Analyzer (TC/EA) paired with a Delta $\mathrm{V}^{\text {Plus }}$ isotope ratio mass spectrometer via a ConFlo III universal interface (Isomass Scientific Inc., Calgary, AB, Canada). This setup allowed for online conversion of solid phosphate oxygen to $\mathrm{CO}$ gas in an oxygen-free environment. Samples were weighed into $3.5 \times 5 \mathrm{~mm}$ silver cups, folded and sealed, and loaded into an autosampler. The sampler was then flushed with helium and sealed. The TC/EA pyrolyzed the samples, one at a time, in a reactor held at $1450^{\circ} \mathrm{C}$. Oxygen in the sample was converted to $\mathrm{CO}$ gas, by reaction with carbon in the packed reactor column, and was then entrained in $\mathrm{He}$ carrier gas travelling from the reactor, through a gas chromatography (GC) column held at $90^{\circ} \mathrm{C}$

Each analysis sequence included three 30-second-long reference gas analyses, used as a benchmark for gas yield. This was followed by analysis of the sample, dropped at 170 seconds, and lasting 600 seconds total. Thermo Benzoic Acid (Thermo Fisher Scientific, Waltham, MA, USA) was analyzed regularly for quality control and gave an average $\delta^{18} \mathrm{O}$ value of $25.0 \pm 0.2 \%$ for 48 analyses. In addition, Acros (Thermo Fisher Scientific) $\mathrm{Ag}_{3} \mathrm{PO}_{4}$ and $\mathrm{B} 2207 \mathrm{Ag}_{3} \mathrm{PO}_{4}$ (Elemental Microanalysis certified reference material; Okehampton, UK), with values of $12.1 \pm 0.4 \%$ and $21.7 \pm 0.3 \%$, respectively, were analyzed. Values of the Acros and Benzoic standards were determined in-house using the externally calibrated $\mathrm{Ag}_{3} \mathrm{PO}_{4}$ reference materials USGS MR-3 and MR-5 with values of $10.9 \%$ and $29.3 \%$, respectively. Daily calibration was carried out by creating a calibration curve using least squares linear regression of known and measured values of the Acros and $\mathrm{B} 2207 \mathrm{Ag}_{3} \mathrm{PO}_{4}$ standards. A sample size of $300 \mu \mathrm{g}$ was assessed to produce $5.6 \mathrm{~V} \mathrm{CO}$ peaks, which were matched to the standard CO mass 28 peaks. This sample size also complemented the silver phosphate precipitation method, since one $5 \mathrm{mg}$ enamel sample produced enough $\mathrm{Ag}_{3} \mathrm{PO}_{4}$ analyte to run each sample in triplicate. 


\section{RESULTS AND DISCUSION}

\section{1 $\mathrm{Ag}_{3} \mathrm{PO}_{4}$ precipitation}

Our simple precipitation method produced $\mathrm{Ag}_{3} \mathrm{PO}_{4}$ that was bright to golden shades of yellow, typically ranging from 0.7 to $1.7 \mu \mathrm{m}$ in diameter, and was predominantly euhedral and visibly free of any amorphous organic materials (Figure 2). Optimization of our method showed that $1.8 \mathrm{~mL}$ of silver ammine solution produced the highest, most consistent yield of $0.85 \mathrm{mg}$ product per $1 \mathrm{mg}$ sample.

Regardless of the method used, organic matter must be removed from the bioapatite prior to the precipitation of $\mathrm{Ag}_{3} \mathrm{PO}_{4}$, and this step requires 2 to 3 days. ${ }^{36,41}$ Following this pre-treatment, our simplified precipitation method involves only 2 steps: 1) digestion of bioapatite using $\mathrm{HF}$ and 2) precipitation of $\mathrm{Ag}_{3} \mathrm{PO}_{4}$ using silver ammine solution. Table 1 compares our simplified method with two other methods ranging in complexity. ${ }^{36,41}$ On one end of the spectrum, Bellissimo ${ }^{41}$ reports a method with more than 5 additional steps, after the removal of the organic matter, which involves cumbersome titrations and multiple $\mathrm{pH}$ balances prior to precipitating $\mathrm{Ag}_{3} \mathrm{PO}_{4}$. Her method requires $\sim 6$ hours on a hot plate set at $55^{\circ} \mathrm{C} .^{41}$ At the other end of the spectrum, Wiedemann-Bidlack et al ${ }^{36}$ use a method involving only 3 steps; however, this method uses an additional reagent and takes 12 hours for precipitation, adding an additional day to produce $\mathrm{Ag}_{3} \mathrm{PO}_{4} \cdot{ }^{36}$

\subsection{Oxygen isotopic compositions}

The accuracy of our method was tested using the standard NBS120c (Florida phosphate rock). Although the appropriateness of this standard has been questioned, ${ }^{30,34} \mathrm{a}$ number of publications have reported $\delta^{18} \mathrm{O}$ values for this material, and it remains in use as a standard. ${ }^{32,34-35,44-45}$ The mean $\delta^{18} \mathrm{O}$ value of $\mathrm{Ag}_{3} \mathrm{PO}_{4}$ precipitated from NBS $120 \mathrm{c}$ is $21.5 \pm$ 
$0.5 \%(n=7)$. This value and error are comparable with published values for this standard (e.g., $\delta^{18} \mathrm{O}=21.6$ to 22.6 ; Figure 3 ), ${ }^{32,34-35,44-45}$ demonstrating that our simplified method can be used to produce $\delta^{18} \mathrm{O}$ values for comparison with existing data produced by different labs and analytical methods.

We applied our method to both cementum and enamel from modern cow teeth. Analyses of cementum from one tooth were carried out on three separate samples of $\mathrm{Ag}_{3} \mathrm{PO}_{4}$, over two days. The mean $\delta^{18} \mathrm{O}$ value was $9.1 \pm 0.4 \%$ ( $\mathrm{n}=10$; Figure 4$)$. Enamel from the same tooth, prepared in two $\mathrm{Ag}_{3} \mathrm{PO}_{4}$ batches, produced a mean value of $9.6 \pm 0.3 \%$ o $(\mathrm{n}=5$; Figure 4). These data show that enamel and cementum processed with our streamlined $\mathrm{Ag}_{3} \mathrm{PO}_{4}$ precipitation method produced largely consistent oxygen isotope results. These results are consistent with the fact that the cow from which the teeth were extracted lived its entire life in the same geographic location. Therefore, we would not expect major differences between the two dental tissues.

\section{CONCLUSONS}

Traditionally, silver phosphate precipitation methods are lengthy and/or require a relatively large sample size. ${ }^{29-30,33-36,40-43}$ Our simplified method for $\mathrm{Ag}_{3} \mathrm{PO}_{4}$ precipitation combines key attributes from previously published studies by O`Neil et al, ${ }^{30}$ Stephan, ${ }^{33}$ and Wiedemann-Bidlack et $\mathrm{al}^{36}$ while reducing the number of steps and the length of time required to produce organic-free, pure $\mathrm{Ag}_{3} \mathrm{PO}_{4}$ from bioapatite without compromising the reproducibility of the $\delta^{18} \mathrm{O}$ values.

\section{ACKNOWLEDGMENTS}


Financial support was provided by a Natural Sciences and Engineering Research Council (NSERC) Discovery Grant to M. Fayek, a Social Sciences and Humanities Research Council (SSHRC) grant to R. Hoppa and the Canada Research Chairs program.

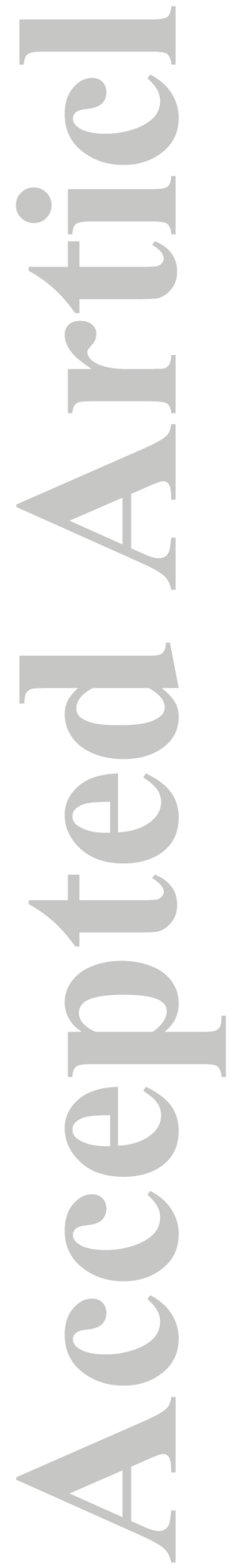




\section{REFERENCES}

1. Epstein S, Buchsbaum R, Lowenstam HA, Urey HC. Revised carbonate-water isotopic temperature scale. Bull Geol Soc Am. 1953;64(11):1315-1326.

2. Kolodny Y, Luz B, Navon,O. Oxygen isotope variations in phosphate of biogenic apatites,

I. Fish bone apatite - rechecking the rules of the game. Earth Planet Sci Lett. 1983;64(3):398404.

3. Longinell A, Nuti S. Oxygen isotope measurements of phosphate from fish teeth and bones. Earth Planet Sci Lett. 1973;20(3):337-340.

4. Longinelli A, Nuti S. Revised phosphate-water isotopic temperature scale. Earth Planet Sci Lett. 1973;19(3):373-376.

5. Longinelli A. Oxygen isotopic composition of orthophosphate from shells of living marine organisms. Nature. 1965;207:716-719.

6. Longinelli A. Ratios of Oxygen-18/Oxygen-16 in phosphate and carbonate form living and fossil marine organisms. Nature. 1966;211:923-927.

7. Longinelli A. Oxygen isotopes in mammal bone phosphate: A new tool for paleohydrological and paleoclimatological research? Geochim Cosmochim Acta. $1984 ; 48(2): 385-390$.

8. Tudge AP. A method of analysis of oxygen isotopes in orthophosphate-its use in the measurement of paleotemperatures. Geochim Cosmochim Acta. 1960;18(1-2):81-93.

9. Urey HC. The thermodynamic properties of isotopic substances. J Chem Soc. 1947;562581.

10. Dansgaard W. Stable isotopes in precipitation. Tellus. 1964;16(4):436-468.

11. Burton J. Bone chemistry and trace element analysis. In: Katzenberg MA, Saunders SR, eds. Biological Anthropology of the Human Skeleton. 2nd ed. Hoboken: Wiley-Liss; 2008:443-460. 
12. Hillson S. Dental Anthropology. Cambridge: Cambridge University Press; 1996.

13. Lee-Thorp JA. Two decades of progress towards understanding fossilization processes and isotopic signals in calcified tissue minerals. Archaeom. 2002;44(3):435-446.

14. Roche D, Ségalen L, Balan E, Delattre S. Preservation assessment of Miocene-Pliocene tooth enamel from Tugen Hills (Kenyan Rift Valley) through FTIR, chemical and stableisotope analyses. J Archaeol Sci. 2010;37(7):1690-1699.

15. Balasse M, Bocherens H, Mariotti A, Ambrose SH. Detection of dietary changes by intratooth carbon and nitrogen isotopic analysis: An experimental study of dentine collagen of cattle (Bos taurus). J Archaeol Sci. 2001;28(3):235-245.

16. Price TD, Bentley A, Luning J, Gronenborn D, Wahl J. Prehistoric human migration in the Linearbandkeramik of Central Europe. Antiquity. 2001;75(289):593- 603.

17. Price TD, Johnson CM, Ezzo JA, Ericson J, Burton JH. Residential mobility in the prehistoric Southwest United States: A preliminary study using strontium isotope analysis. $J$ Archaeol Sci. 1994);21(3):315-330.

18. Richards MP, Mays S, Fuller BT. Stable carbon and nitrogen isotope values of bone and teeth reflect weaning age at the medieval Wharram Percy site, Yorkshire, UK. Am J Phys Anthro. 2002;119(3):205-210.

19. Fleet ML. Carbonated Hydroxyapatite: Materials, Synthesis, and Applications. London: Taylor and Francis; 2014.

20. Hughes JM, Rakovan JF. Structurally robust, chemically diverse: apatite and apatite supergroup minerals. Elements. 2015;11(3):165-170.

21. Koch PL, Tuross N, Fogel ML. The effects of sample treatment and diagenesis on the isotopic integrity of carbonate in biogenic hydroxylapatite. J Archaeol Sci. 1997;24(5):417429. 
22. Feranec RS. Stable isotopes, hypsodonty, and the paleodiet of Hemiauchenia (Mammalia: Camelidae): a morphological specialization creating ecological generalization. Paleobiol. $2003 ; 29(2): 230-242$.

23. Clementz MT, Goswami A, Gingerich PD, Koch PL. Isotopic records from early whales and sea cows: contrasting patterns of ecological transition. J Vert Paleontol. 2006;26(2):355370.

24. Fox DL, Koch PL. Tertiary history of C4 biomass in the Great Plains, USA. Geology. 2003;31 (9):809-812.

25. Matthews C, Longstaffe FJ, Ferguson S. Dentine oxygen isotopes $\left(\delta^{18} \mathrm{O}\right)$ as a proxy for odontocete distributions and movements. Ecol Evol. 2016;6(14):4643-4653.

26. Kohn MJ, Cerling TE. Stable isotope compositions of biological apatite. In: Kohn MJ, Rakovan J, Hughes JM, eds. Phosphates. Geochemical, Geobiological, and Materials Importance. Reviews in Mineralogy and Geochemistry. Washington, DC: Mineralogical Society of America; 2002:455-488).

27. Firsching FH. Precipitation of silver phosphate from homogeneous solution. Anal Chem. $1961 ; 33(7): 873-874$

28. Baxter GP, Jones G. A revision of the atomic weight of phosphorus. J Am Chem Soc. 1910;32(3):298-318.

29. Crowson RA, Showers WJ, Wright EK, Hoering TC. Preparation of phosphate samples for oxygen isotope analysis. Anal Chem. 1991;63(20):2397-2400.

30. O’Neil JR, Roe LJ, Reinhard E, Blake RE. A rapid and precise method of oxygen isotope analysis of biogenic phosphate. Israel J Earth Sci. 1994;43:203-212.

31. Wright EK, Hoering TC. A new method for oxygen isotope analysis of phosphates: Hydrogen reduction of silver phosphate. In: Annual Report of the Director Geophysical Laboratory. Carnegie Institution; 1990:131-134. 
32. Lecuyer C, Grandjean P, O’Neil JR, Cappetta H, Martineau F. Thermal excursions in the ocean at the Cretaceous-Tertiary boundary (northern Morocco): $\delta 180$ record of phosphatic fish debris. Paleogeog Paleoclimat Paleoecol. 1993;105(3-4):234-243.

33. Stephan E. Oxygen isotope analysis of animal bone phosphate: Method refinement, influence of consolidants, and reconstruction of palaeotemperatures for Holocene sites. $J$ Archaeol Sci. 2000;27(6):523-535.

34. Dettman DL, Kohn MJ, Quade J, Ryerson FJ, Ojha TP, Hamidullah S. Seasonal stable isotope evidence for a strong Asian monsoon throughout the past 10.7 m.y. Geology. 2001;29(1):31-34.

35. Vennemann TW, Fricke HC, Blake RE, O’Neil JR, Colman A. Oxygen isotope analysis of phosphates: a comparison of techniques for analysis of Ag3PO4. Chem Geol. 2002;185(34):321-336.

36. Wiedemann-Bidlack FB, Colman AS, Fogel ML. Phosphate oxygen isotope analysis on microsamples of bioapatite: removal of organic contamination and minimization of sample size. Rapid Commun Mass Spectrom. 2008;22(12):1807-1816.

37. Grimes V, Pellegrini M. A comparison of pretreatment methods for the analysis of phosphate oxygen isotope ratios in bioapatite. Rapid Commun Mass Spectrom. 2013;27(3):375-90.

38. Stuart-Williams HL, Le Q, Schwarcz HP. Oxygen isotopic analysis of silver orthophosphate using a reaction with bromine. Geochim Cosmochim Acta. 1995;59(18):38373841.

39. Stuart-Williams HL. Analysis of the variation of oxygen isotopic composition of mammalian bone phosphate. Ph.D. thesis, School of Geography and Earth Sciences, McMaster University, Hamilton, 1996. 
40. Brady AL, White CD, Longstaffe FJ, Southam G. Investigating intra-bone isotopic variations in bioapatite using IR-laser ablation and micromilling: Implications for identifying diagenesis? Palaeogeog Palaeoclimat Palaeoecol. 2008;266(3):190-199.

41. Bellissimo NS. Origins of stable isotopic variations in Late Pleistocene horse enamel and bone from Alberta. MSc thesis, University of Western Ontario 2013;101 pp.

42. Webb EC, White CD, Longstaffe FJ. Exploring geographic origins at Cahuachi using stable isotopic analysis of archaeological human tissues and modern environmental waters. Internat J Osteoarch. 2013;23(6):698-715.

43. Mine AH, Waldeck A, Olack G, Hoerner ME, Alex S, Colman AS. Microprecipitation and $\delta^{18} \mathrm{O}$ analysis of phosphate for paleoclimate and biogeochemistry research. Chem Geol. 2017;460:1-14.

44. Tütken T, Vennemann TW, Janz H, Heizmann HEP. Paleoenvironment and paleoclimate of the Middle Miocene Lake in the Steinheim basin, SW Germany, a reconstruction from C, O, and Sr isotopes of fossil remains. Paleogeog Paleoclimat Paleoecol. 2006;241:457-491.

45. Chenery C, Müldner G, Evans J, Eckardt H, Lewis M. Strontium and stable isotope evidence for diet and mobility in Roman Gloucester, UK. J Archaeol Sci. 2010;37(1):150163.

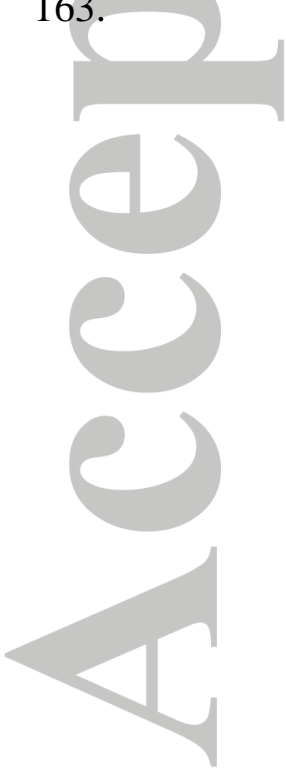


Table 1. Comparison of the simplified $\mathrm{Ag}_{3} \mathrm{PO}_{4}$ precipitation method presented in this study with two other methods ranging in complexity. Starting material for all methods is organicfree bioapatite.

\begin{tabular}{|c|c|c|c|}
\hline & This Study & Wiedemann-Bidlack et al $^{36}$ & Bellissimo $^{41}$ \\
\hline Step 1 & $\begin{array}{l}\text { dissolve in } 200 \mu \mathrm{L} 2 \mathrm{M} \mathrm{HF} \\
(24 \mathrm{hrs} .)\end{array}$ & $\begin{array}{c}\text { dissolve in } 100 \mu \mathrm{L} 2 \mathrm{M} \mathrm{HNO}_{3} \\
(20 \mathrm{hrs} .)\end{array}$ & $\begin{array}{l}\text { neutralize samples } \\
\text { with } 8 \mathrm{M} \mathrm{KOH}\end{array}$ \\
\hline Step 2 & $\begin{array}{c}\text { precipitate } \mathrm{Ag}_{3} \mathrm{PO}_{4} \text { with } 1.8 \\
\text { mL silver ammine solution } \\
\left(50^{\circ} \mathrm{C},<5 \text { mins. }\right)\end{array}$ & add $33 \mu \mathrm{L} 2 \mathrm{M}$ HF & $\begin{array}{l}\text { add } 3 \mathrm{~mL} 0.5 \mathrm{M} \\
\mathrm{Pb}\left(\mathrm{C}_{2} \mathrm{H}_{3} \mathrm{O}_{2}\right)_{2}\end{array}$ \\
\hline Step 3 & & $\begin{array}{l}\text { precipitate } \mathrm{Ag}_{3} \mathrm{PO}_{4} \text { with } 1550 \\
\mu \mathrm{L} \text { silver ammine solution } \\
\quad\left(50^{\circ} \mathrm{C}, 12 \mathrm{hrs} .\right)\end{array}$ & $\begin{array}{c}\text { adjust } \mathrm{pH} \text { to } 5.5-5.7 \\
\text { with } 8 \mathrm{M} \text { and } 4 \mathrm{M} \mathrm{KOH}\end{array}$ \\
\hline Step & & & add $2 \mathrm{~mL} 0.25 \mathrm{M} \mathrm{HNO}_{3}$ \\
\hline Step 5 & & & $\begin{array}{c}\text { add } 2 \mathrm{~mL} 0.25 \mathrm{M} \\
\left(\mathrm{NH}_{4}\right)_{2} \mathrm{SO}_{4}\end{array}$ \\
\hline Step 6 & & & $\begin{array}{l}\text { 2-3 drops bromothymol } \\
\text { blue solution }\end{array}$ \\
\hline Step & & & $\begin{array}{l}\text { adjust } \mathrm{pH} \text { to } 5.5-6.5 \\
\text { with } 4 \mathrm{M} \mathrm{KOH}\end{array}$ \\
\hline Step 8 & & & add $1 \mathrm{~mL} \mathrm{NH}_{4} \mathrm{OH}$ \\
\hline Step 9 & & & $\begin{array}{l}\text { add } 1.5 \mathrm{~mL} \\
\left(\mathrm{NH}_{4}\right)\left(\mathrm{NO}_{3}\right)\end{array}$ \\
\hline Step 10 & & & $\begin{array}{c}\text { precipitate } \mathrm{Ag}_{3} \mathrm{PO}_{4} \\
\text { with } 10 \mathrm{~mL} \\
\text { ammoniacal silver } \\
\text { solution }\left(55^{\circ} \mathrm{C}, 6-\right. \\
6.5 \mathrm{hrs} .)\end{array}$ \\
\hline
\end{tabular}




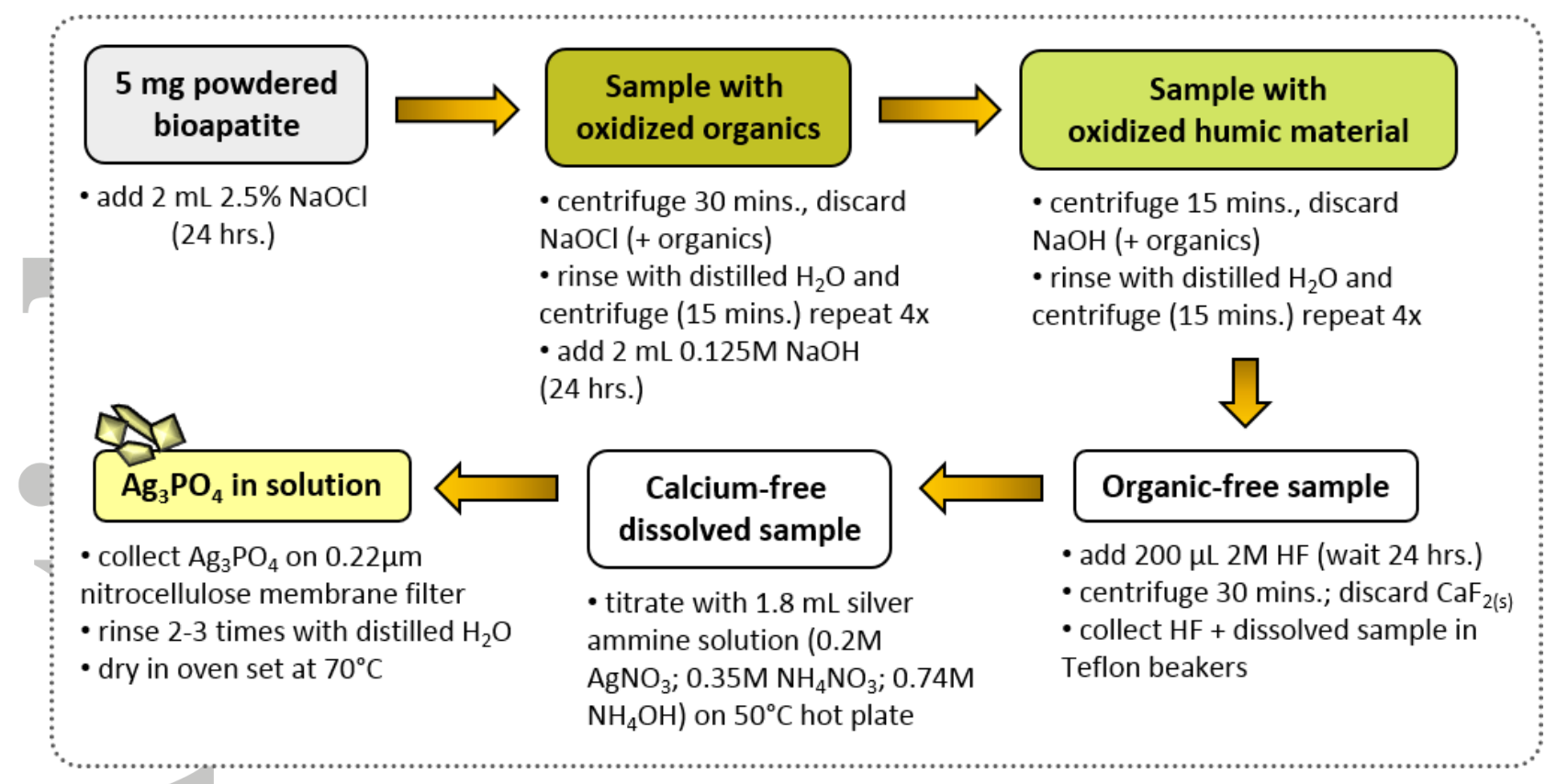

Fig. 1. Flowchart of organic matter removal pre-treatment and $\mathrm{Ag}_{3} \mathrm{PO}_{4}$ precipitation method used in this study. 

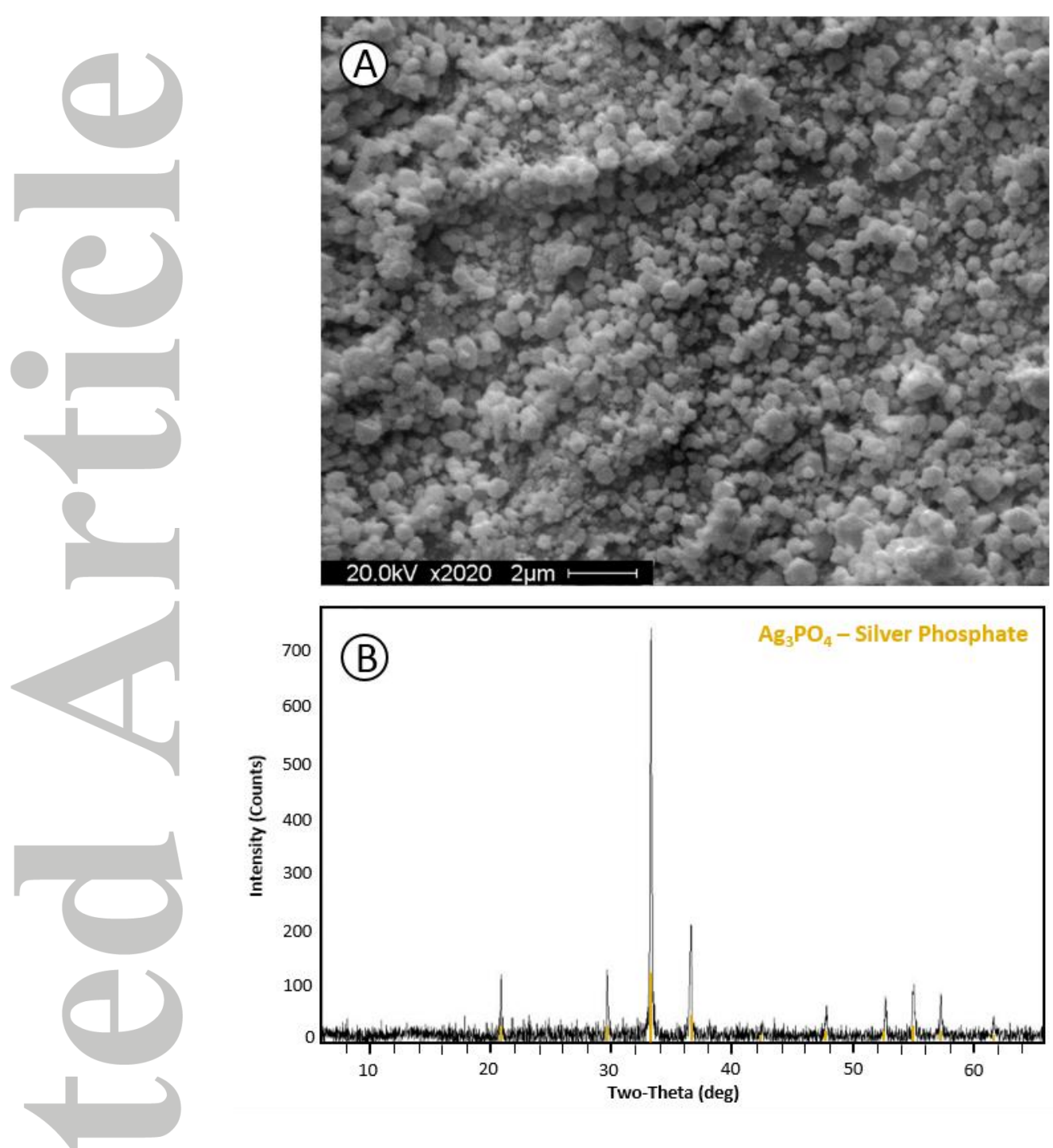

Fig. 2. A) Scanning electron microscopy (SEM) image of euhedral $\mathrm{Ag}_{3} \mathrm{PO}_{4}$ grains free of amorphous organic materials; B) X-ray diffraction (XRD) pattern of $\mathrm{Ag}_{3} \mathrm{PO}_{4}$ precipitated from cow cementum. Spectrum shows reflections at all angles expected of $\mathrm{Ag}_{3} \mathrm{PO}_{4}$ with no residual organic contamination. 

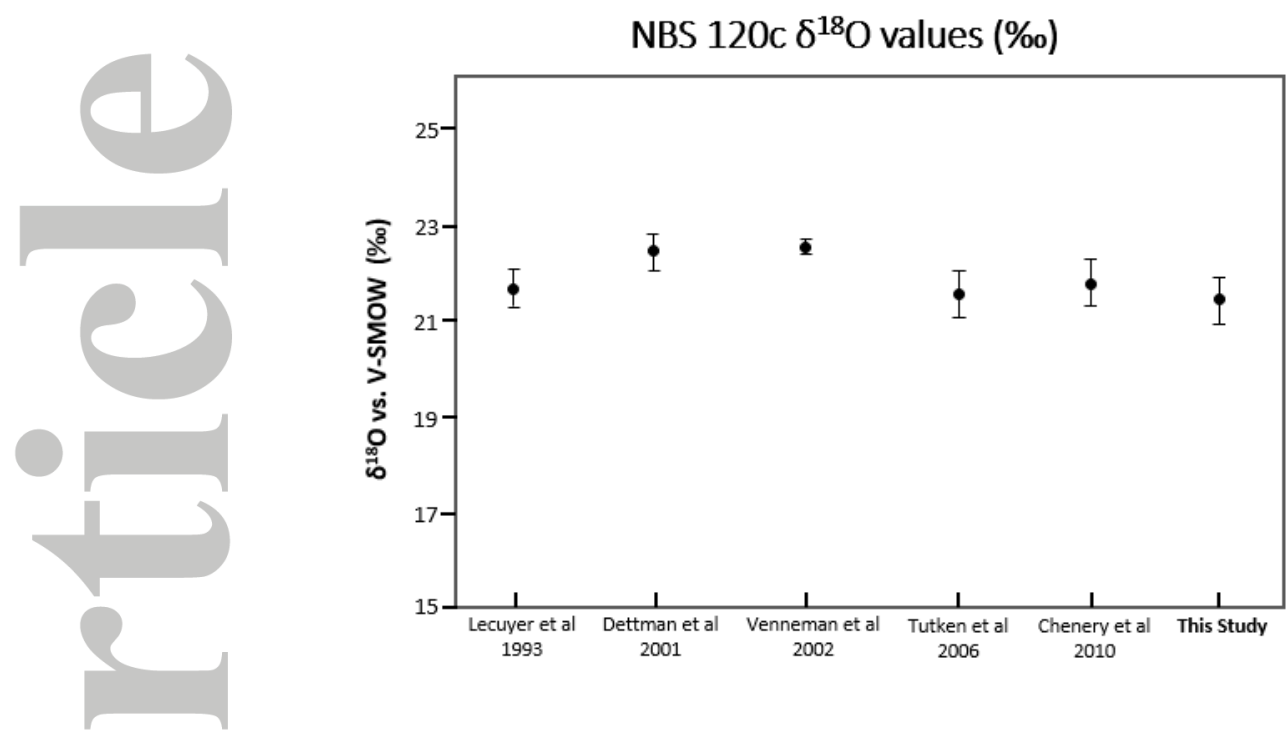

Fig. 3. Comparison of published $\delta^{18} \mathrm{O}$ values for NBS 120c phosphate rock and the mean $\delta^{18} \mathrm{O}$ value obtained in this study. Error bars $=95 \%$ confidence interval $(\mathrm{CI})$.

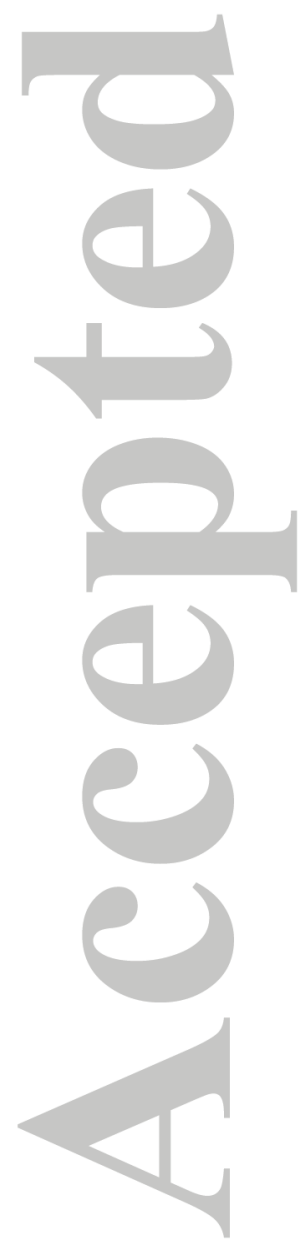




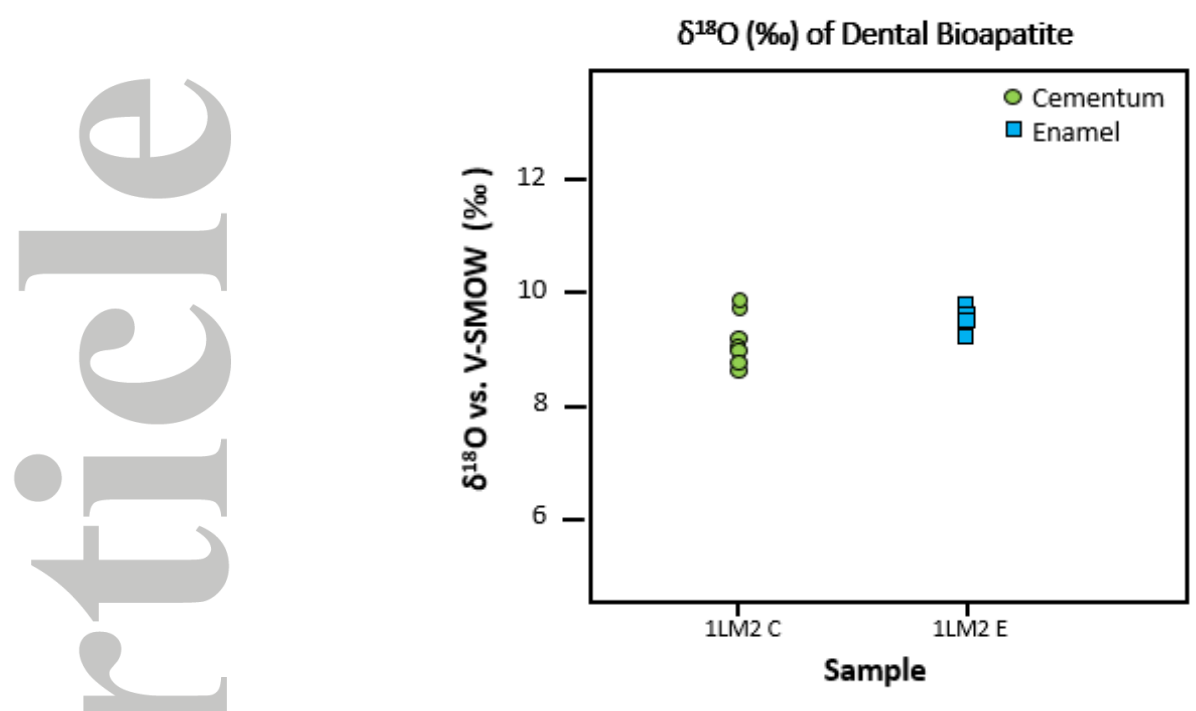

Fig. 4. $\delta^{18} \mathrm{O}$ values of $\mathrm{Ag}_{3} \mathrm{PO}_{4}$ precipitated from cow enamel and cementum using the method presented in this study.

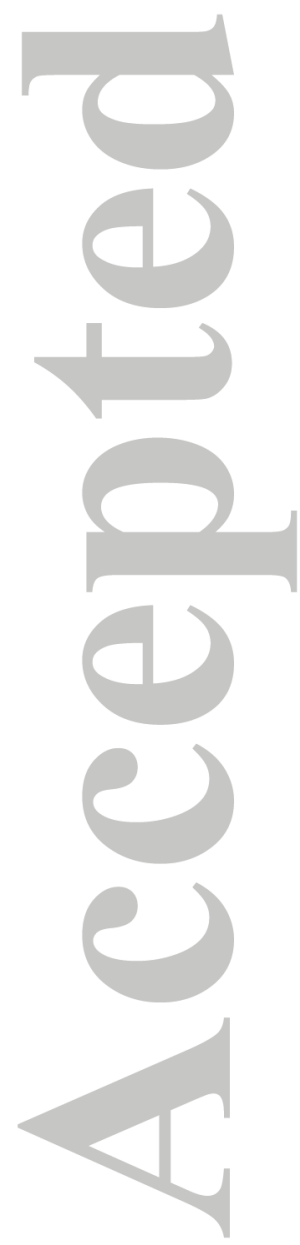

